\title{
Resistance and resilience of benthic biofilm communities from a temperate saltmarsh to desiccation and rewetting
}

\author{
Boyd A McKew, Joe D Taylor, Terry J McGenity and Graham JC Underwood \\ Department of Biological Sciences, University of Essex, Wivenhoe Park, Colchester, UK
}

\begin{abstract}
Periods of desiccation and rewetting are regular, yet stressful events encountered by saltmarsh microbial communities. To examine the resistance and resilience of microbial biofilms to such stresses, sediments from saltmarsh creeks were allowed to desiccate for 23 days, followed by rewetting for 4 days, whereas control sediments were maintained under a natural tidal cycle. In the top $2 \mathrm{~mm}$ of the dry sediments, salinity increased steadily from 36 to 231 over 23 days, and returned to seawater salinity on rewetting. After 3 days, desiccated sediments had a lower chlorophyll $a$ (Chl a) fluorescence signal as benthic diatoms ceased to migrate to the surface, with a recovery in cell migration and $\mathrm{Chl}$ a fluorescence on rewetting. Extracellular $\beta$-glucosidase and aminopeptidase activities decreased within the first week of drying, but increased sharply on rewetting. The bacterial community in the desiccating sediment changed significantly from the controls after 14 days of desiccation (salinity 144). Rewetting did not cause a return to the original community composition, but led to a further change. Pyrosequencing analysis of 16S rRNA genes amplified from the sediment revealed diverse microbial responses, for example desiccation enabled haloversatile Marinobacter species to increase their relative abundance, and thus take advantage of rewetting to grow rapidly and dominate the community. A temporal sequence of effects of desiccation and rewetting were thus observed, but the most notable feature was the overall resistance and resilience of the microbial community.
\end{abstract}

The ISME Journal (2011) 5, 30-41; doi:10.1038/ismej.2010.91; published online 1 July 2010

Subject Category: microbial population and community ecology

Keywords: saltmarsh; desiccation; microbial community; stress; biofilm; microphytobenthos

\section{Introduction}

Microorganisms inhabiting intertidal zones must be able to tolerate rapid and repeated fluctuations in environmental conditions including temperature, light and salinity. This ability is particularly important in intertidal sediments, in which microphytobenthic (MPB) algae form extensive biofilms and are often the major primary producers (Underwood and Kromkamp, 1999). The combination of various stress factors (physical disturbance, light exposure, grazing and desiccation) usually results in a monomodal distribution of biomass and primary production of MPB across intertidal flats, with the peak between mid-tide level and mean high water neap tide (Guarini et al., 2000). High densities of MPB are also often found in unshaded saltpans and creeks (Bellinger et al., 2005). The risk of desiccation increases further up the shore (Rothrock

Correspondence: BA McKew, Department of Biological Sciences, University of Essex, Wivenhoe Park, Colchester CO4 3SQ, UK. E-mail: bamcke@essex.ac.uk

Received 1 March 2010; revised 27 May 2010; accepted 30 May 2010; published online 1 July 2010 and Garcia-Pichel, 2005). For example, the upper levels of the Colne Point saltmarsh (see Materials and methods for location) regularly receive no tidal cover for 5 days around neap tides, and up to 21 days when coupled with low amplitude spring tides during summer. Consequently, pore-water salinities in upper marsh sediments are more extreme than those in sediments lower in the tidal prism, with salinity ranges in upper saltmarsh sediments (minimum, 16; maximum, 210) far greater than those in the lower marsh (minimum, 18; maximum 70) or mudflat (minimum 22; maximum 39) (Underwood, 1997).

Desiccation and consequent reduction in water activity $\left(A_{\mathrm{w}}\right)$ and increase in salinity imparts considerable osmotic and matric stress on microorganisms and can lead to decreases in cytoplasmic volume, damage to membranes, proteins and nucleic acids and cellular lysis (Csonka, 1989; Potts, 1999). Numerous unicellular algae (Kirst, 1990; Chen et al., 2008) and prokaryotes (Csonka, 1989; Potts, 1999) have mechanisms to tolerate such stresses. MPB (Underwood, 1997), bacterial and archaeal (Rothrock and Garcia-Pichel, 2005) communities exhibit significant decreases in species 
richness and diversity as periods of desiccation increase, suggesting that desiccation is a major stress selecting for suitably adapted microorganisms. Tidal inundation adds an additional stress to the sediment community with a sudden return to earlier levels of salinity and $A_{\mathrm{w}}$.

In soils, drying and rewetting induce cellular lysis that alters microbial community composition (Kieft et al., 1987; Fierer et al., 2003), and the drying of river beds results in large reductions in microbial activity and biomass (Amalfitano et al., 2008). However, despite their pivotal function in estuarine and coastal carbon cycling (Hoppe, 1983) and the increasing risk of arid summers (IPCC, 2007), there is a paucity of information on how desiccation and reflooding affect saltmarsh microbial communities. Therefore, we tested the effects of sediment desiccation and rewetting on the behaviour, abundance, structure and function of saltmarsh sediment biofilms to determine their resistance (measure of how little the system and microbial community change in response to desiccation) and resilience (the ability of the system and microbial community to return to its earlier state) to such events. In particular, we measured the effects of desiccation on dissolved organic carbon (DOC), and on watersoluble carbohydrates, which form a large part of the labile extracellular polymeric substance (EPS) pool that is typically consumed rapidly by bacteria in such sediments (Hofmann et al., 2009). $\beta$-glucosidase and aminopeptidase activities provide an indicator of such bacterial activity, as these extracellular enzymes reflect heterotrophic activity associated with the degradation of EPS (Simon et al., 2002; Haynes et al., 2007) Quantitative-PCR of the $16 \mathrm{~S}$ rRNA gene was used to estimate bacterial and archaeal biomass, and a detailed analysis of changes in the bacterial community composition was carried out by 454 pyrosequencing of 16S rRNA genes.

\section{Materials and methods}

Experimental overview

A total of 78 sediment cores $(10 \mathrm{~cm}$ diameter, $10 \mathrm{~cm}$ deep) were taken from a creek in the upper Colne Point, saltmarsh $\left(51^{\circ} 47^{\prime} \mathrm{N}, 1^{\circ} 3^{\prime} \mathrm{E}\right)$ UK in summer, August 2007. This is a typical NW European backbarrier marsh with a meandering dendritic tidal creek network (for description see Underwood et al., 1998). Cores were placed in 12 tanks (26 l), with six cores in each for analysis on days 1, 3, 7, 14, 23 and 28. Six tanks were subjected to a drying period of 23 days. Six control tanks were connected to pumps on a tidal delay timer (moving high tide forwards by 50 min every $24 \mathrm{~h}$ ), which flooded the tanks with seawater to $5 \mathrm{~cm}$ above the core surface for $2 \mathrm{~h}$ at each of two daily high tides. After high tide, tanks drained to their individual sump tank. Evaporation losses were replaced with sterile distilled water to maintain constant salinity. At day 24, the remaining desiccated cores were reflooded with seawater for $2 \mathrm{~h}$ at each high tide for 4 further days before analysis. The tanks were positioned in sunlight in a temperature-controlled greenhouse.

At each time point, one core from each tank was analysed at morning low tide. After thermal and fluorescence imaging, 10 minicores (top $2 \mathrm{~mm}$ of surface sediment and $1.2 \mathrm{~cm}$ diameter unless stated) were taken from each large core for analysis. Five were analysed immediately for pore-water salinity, $A_{\mathrm{w}}$ (3 cm diameter), water content, $\beta$-glucosidase and aminopeptidase activity. The remaining minicores were stored at $-20^{\circ} \mathrm{C}$ for later analysis of chlorophyll $a(\mathrm{Chl} a$ ), carbohydrates, organic carbon, and hydrolysing enzyme activity, and at $-80^{\circ} \mathrm{C}$ for nucleic acid extraction.

\section{Surface temperature}

Surface temperature of the sediment was recorded with an NEC Thermo Tracer TH7100 infrared thermal imaging camera.

\section{Surface Chl a fluorescence}

Fluorescence imaging (Oxborough et al., 2000; Underwood et al., 2005) was used to image Chl a fluorescence at steady state $\left(F^{\prime}\right)$ to provide a measure for surface MPB biomass (triplicate images per core). On day 23, imaging over the whole day at two hourly intervals was conducted.

\section{Salinity, $\mathrm{A}_{w}$ and water content}

Pore water was centrifuged from sediment minicores $(13000 \mathrm{~g})$ and the salinity was measured using a Leica refractometer. Sediment $A_{\mathrm{w}}$ was measured at $25^{\circ} \mathrm{C}$ using a Novasina Aw Sprint TH 500. Water content was determined by weighing minicores before and after oven drying at $80^{\circ} \mathrm{C}$ for $24 \mathrm{~h}$.

\section{Chl a analysis}

Minicores were freeze dried and ground before adding $4 \mathrm{ml}$ of $\mathrm{MgCO}_{3}$-saturated methanol, mixing, then incubating in the dark at $4{ }^{\circ} \mathrm{C}$ for $24 \mathrm{~h}$. The extract was mixed and centrifuged (3000 g, $15 \mathrm{~min}$ ) and absorbance of the supernatant was measured at 665 and $750 \mathrm{~nm}$ before and after acidification with HCl (Lorenzen, 1967). The phaeo-pigment-corrected Chl $a$ concentration was calculated $\left(\mathrm{mgg}^{-1}\right.$ dry weight of sediment) by use of appropriate equations (Stal et al., 1984).

Water-soluble carbohydrate analysis

Minicores were freeze dried, ground, suspended in $5 \mathrm{ml}$ of $\mathrm{NaCl}(2.5 \%)$ and incubated for $30 \mathrm{~min}$ at $25^{\circ} \mathrm{C}$. After centrifugation $(3000 \mathrm{~g}, 15 \mathrm{~min}), 400 \mu \mathrm{l}$ of the supernatant was analysed using the phenolsulphuric acid assay (Dubois et al., 1956) as earlier described (Hanlon et al., 2006). 
Dissolved organic carbon

Total DOC was measured on a Shimadzu TOC-VCSH Total Organic Carbon Analyser.

\section{Enzyme activity}

Maximum potential rates of extracellular $\beta$-glucosidase and aminopeptidase activity were determined using fluorescently labelled substrates (Hoppe, 1983). Sediment cores were ground and incubated $\left(25^{\circ} \mathrm{C}, 110\right.$ r.p.m.) in $15 \mathrm{ml}$ of ASW (Berges et al., 2001), $0.2 \% \mathrm{w} / \mathrm{v}$ sodium azide (to prevent de novo enzyme production) and saturating concentrations $(1 \mathrm{mM})$ of labelled substrate MUF- $\beta$-D-glucopyranoside or leucine-7-amino-methylcoumarin earlier dissolved in methyl-cellusolve (Sigma-Aldrich, Dorset, UK). Controls were boiled to denature all enzymes before substrate addition and to differentiate substrate release unrelated to enzyme activity. A total of $2.5 \mathrm{ml}$ subsamples were taken hourly, added to $0.2 \mathrm{ml}$ of $0.2 \mathrm{~mm}$ borate buffer ( $\mathrm{pH} \mathrm{10)}$, centrifuged $(3000 \mathrm{~g}, 15 \mathrm{~min})$, before measuring fluorescence (365 nm excitation, $445 \mathrm{~nm}$ emission) in a PerkinElmer (Waltham, MA, USA) fluorometer LS50. Maximum potential enzyme activity rates were calculated based on rate of MUF or coumarin cleavage.

Bacterial community analysis

RNA and DNA were co-extracted. RNA was isolated, the V3 section of the 16S rRNA gene was reversetranscribed, PCR amplified and used to analyse changes in the active bacterial community by DGGE. The DNA fraction was used to quantify both Bacterial and Archaeal 16S rRNA gene abundance by Q-PCR and to construct bacterial PCR amplicon libraries of the 16S rRNA gene by 454 pyrosequencing. For detailed protocols (including DNA/RNA extraction, RT-PCR DGGE, Q-PCR and 16S rRNA gene library construction), see Supplementary Information.

\section{Statistical analysis}

Analysis of variance with Tukey's HSD multiple comparison tests and canonical correspondence analysis was performed using XLSTAT Version 2008.2.03 (Addinsoft, Paris, France).

\section{Results}

Over the 23-day desiccation period, pore-water salinity in the surface sediments increased steadily from 36 to 231 (Figure 1a) representing a significant $(P<0$. 001) increase from day 7 (salinity 83). This was coupled with significant $(P<0.001)$ decreases in both $A_{\mathrm{w}}$ (Figure 1b) and sediment water content (Figure 1c) from 0.98 to 0.84 and $71-28 \%$, respectively. In contrast, in the control sediments, the pore-water salinity, $A_{\mathrm{w}}$, and water content remained constant throughout the period at 36, 0.98 and

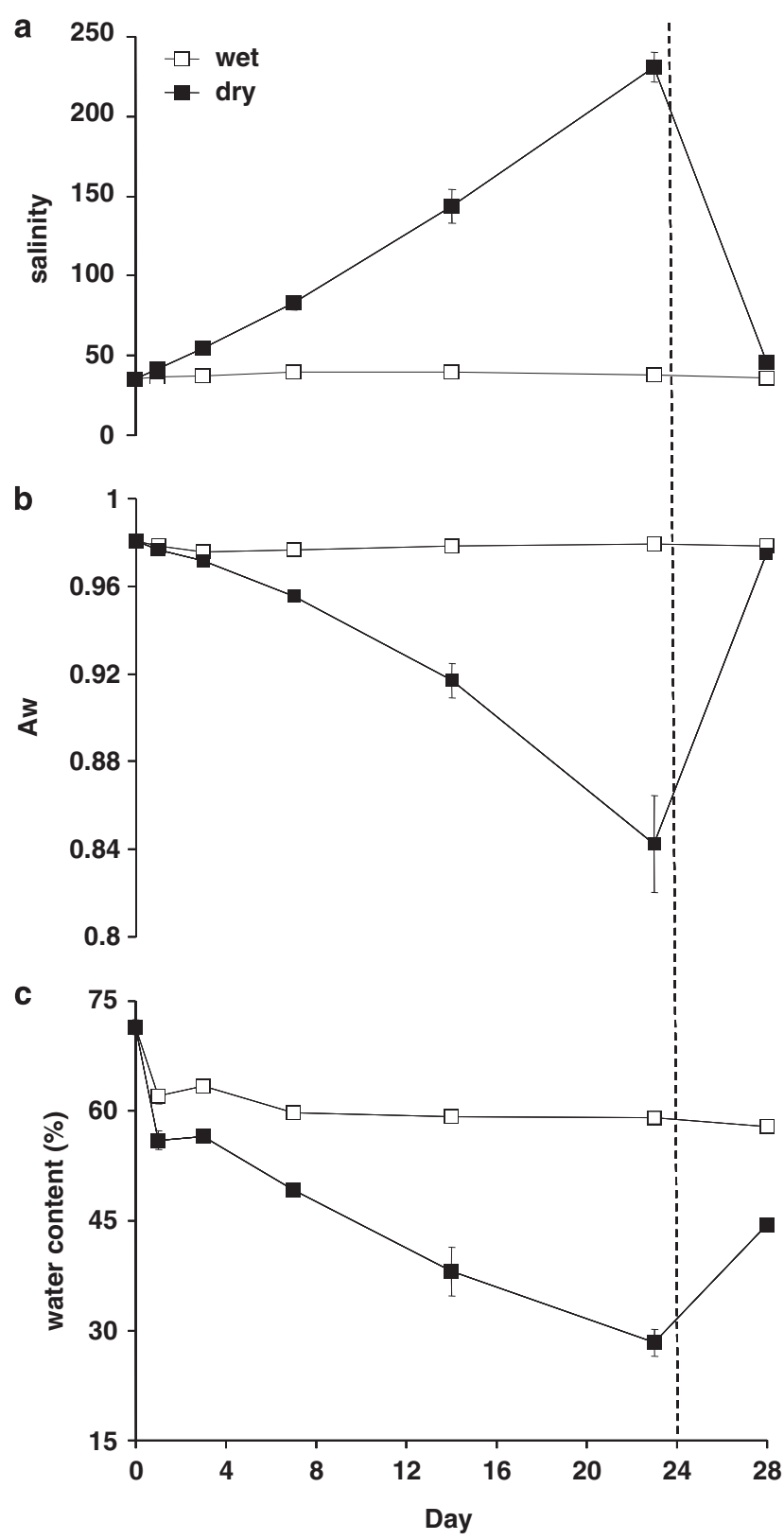

Figure 1 (a) Pore-water salinity, (b) water activity $\left(A_{\mathrm{w}}\right)$ and (c) water content of the desiccated sediments and wet control sediments that were subjected to tidal inundation. Dotted vertical line represents the point at which tidal inundation of the desiccated sediments resumed (means \pm s.e.; $n=6$ ).

$58-62 \%$, respectively. Thermal imaging showed that sediment surface temperatures fluctuated with natural daily changes (ranging from 19 to $26^{\circ} \mathrm{C}$ ). Up to day 7 , there was no difference in surface temperature between the desiccating and wet sediments, but at days 14 and 23, the surface temperature of the drying sediments was $1-1.4^{\circ} \mathrm{C}$ higher.

The surface MPB was imaged by Chl $a$ fluorescence (Figures 2a and d) and consisted primarily of diatoms not only from the genera Navicula, but also Nitzschia, Haslea, Gyrosigma and Pleurosigma. Living diatoms were identified by the morphology 

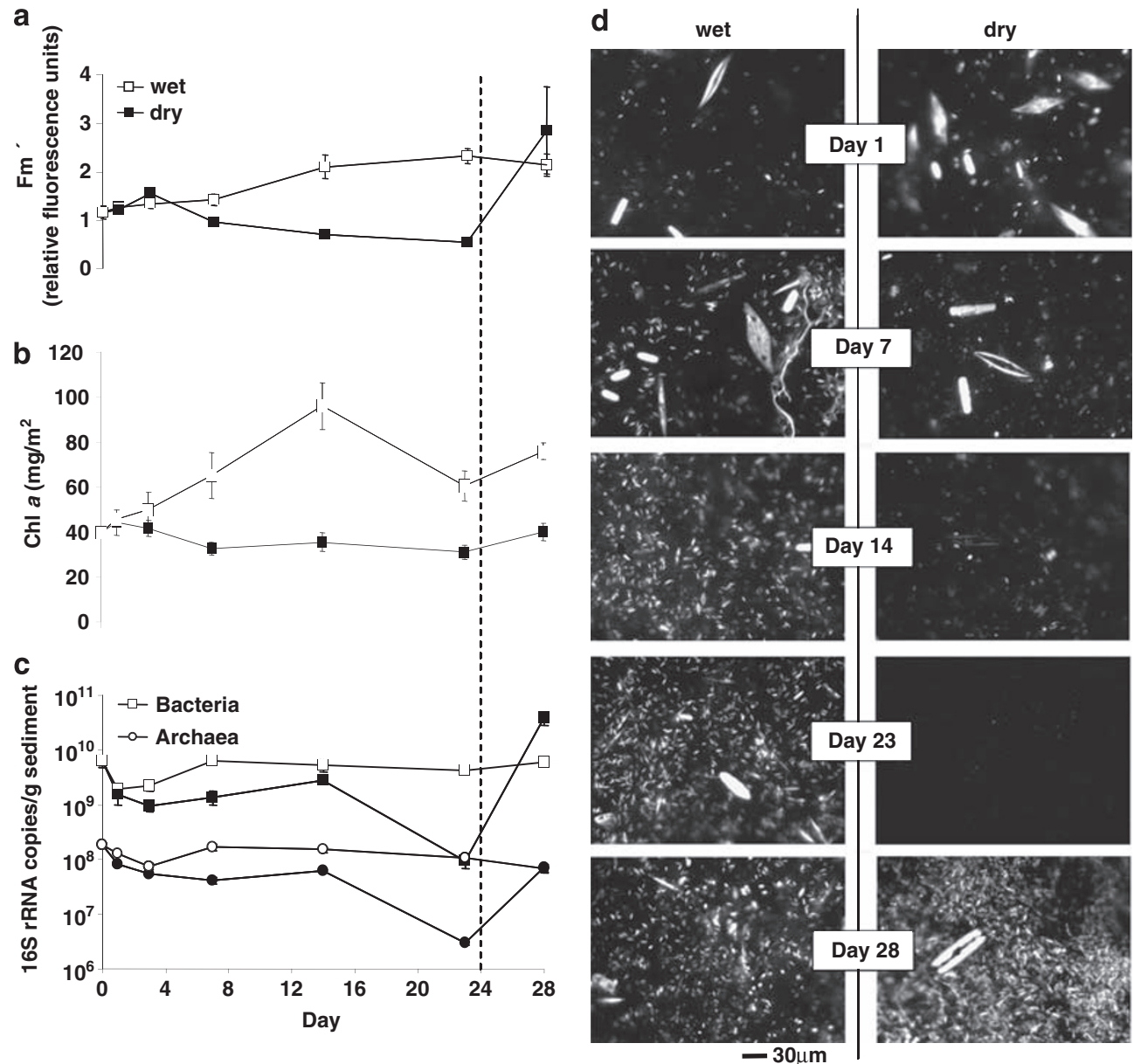

Figure 2 (a, d) Surface abundance of MPB shown by high-resolution Chl $a$ fluorescence imaging, (b) Chl $a$ concentrations and (c) copies of archaeal and bacterial 16S rRNA genes in desiccated and wet control sediments. Dotted vertical line represents the point at which tidal inundation of the desiccated sediments resumed (means \pm s.e.; $n=6$ ).

of chloroplasts and valve shape and structure (Round et al., 1990; Underwood, 1994). In the controls, MPB continued diel vertical migration in synchrony with daylight and tidal cycles (data not shown), and the surface fluorescence signal increased with time. In the desiccating sediments, the surface MPB biomass did not differ significantly from the wet sediments over the first 3 days, but then decreased significantly $(P<0.05)$ from day 7 (salinity 83) to day 23 (salinity 144) (Figure 2a), at which stage no diatoms were imaged on the surface (Figure 2d). Although Chl $a$ fluorescence and diatom numbers decreased on the surface of desiccating sediments, total Chl $a$ concentrations (top $2 \mathrm{~mm}$ ) increased significantly $(P<0.001)$ with desiccation, up to a maximum at day 14 (Figure 2b). On rewetting, there was a recovery of the $\mathrm{Fm}^{\prime}$ signal (Figure 2a), and a significant increase in the density of fluorescent cells on the surface of desiccated cores, with small naviculoid cells dominating the assemblage (Figure 2d).

Bacterial and archaeal 16S RNA gene abundance (Figure 2c) were, respectively, $10^{9}-10^{10}$ and $10^{8}$ copies per $g$ at the start of the experiment. However, on sediment desiccation, gene abundance of both groups decreased significantly $(P<0.01)$ by approximately two orders of magnitude at the most extreme (day 23, salinity 231). After rewetting of the sediments, gene abundance of Bacteria and Archaea returned to levels similar to, or higher than, before desiccation (Figure 2c). Gene copy number is an indicator of cell number, but is dependent on the precise species composition; on average, bacterial species have 4.08 copies of 16S rRNA genes per cell compared with 1.77 copies for Archaea (Lee et al., 2009).

Extracellular enzyme activities in the wet control cores fluctuated slightly over the course of the experiment, but with no overall pattern of decrease or increase (Figures 3a and b). In contrast, enzyme activities were reduced significantly $(P<0.01)$ in the desiccating sediments by day 14 (salinity 144). By day 23 (salinity 231), aminopeptidase activity was 4.5 times lower than in the wet controls. The $\beta$-glucosidase activity decreased rapidly in the desiccating sediments (Figure 3a) and was 2.5 times lower than in the wet controls by day 7 (salinity 83). On rewetting, the activity of both enzymes increased significantly (Figures $3 \mathrm{a}$ and $\mathrm{b}$ ). 
34

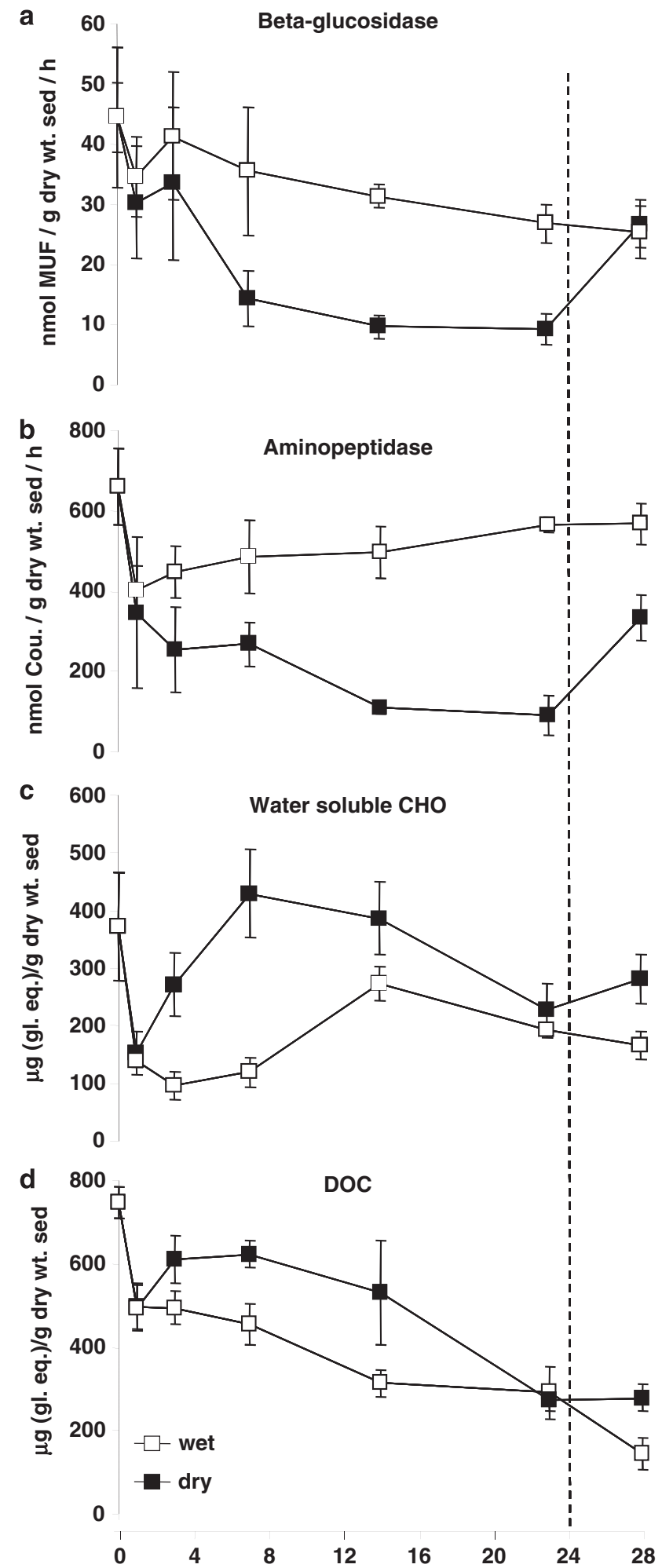

Figure 3 (a) Extracellular $\beta$-glucosidase activity, (b) aminopeptidase activity, (c) water-soluble carbohydrate and (d) DOC in desiccated and wet control sediments. Dotted vertical line represents the point at which tidal inundation of the desiccated sediments resumed (means \pm s.e.; $n=6$ ).

Concentrations of water-soluble carbohydrate decreased rapidly in both the control and desiccated cores over the first $24 \mathrm{~h}$. The concentration subsequently increased in the desiccated cores and was significantly higher than in the controls. DOC concentrations showed a similar pattern, though the difference between control and desiccated sediments had diminished by day 23. The decreases in $\beta$-glucosidase activity in the desiccated cores were not correlated with concentrations of readily degradable carbohydrate and DOC (Figures 3c and d), both of which remained significantly higher in the desiccating sediments (for example water-soluble carbohydrate was 3.6 times higher in the desiccating sediments at day 7).

Changes in composition of the active bacterial community were monitored by $16 \mathrm{~S}$ rRNA RT-PCR DGGE. The DGGE profiles were very similar between replicates and so were combined to produce the composite gel image (Figure 4a). There were minimal changes in the active bacterial community in the wet controls during the experiment, visualized both by DGGE profiles (Figure 4a) and the CCA analysis based on the intensity of individual bands in replicate DGGE profiles (Figure 4b). In contrast, the active bacterial community in the desiccating sediments changed from day 14 (salinity 144), with a clear difference by day 23 (Figure 4a, lane D23, salinity 231). After reflooding the desiccated sediments, the active bacterial community did not return to its earlier composition, but changed further (Figure 4a, lane R28; Figure 4b), demonstrated by the appearance of new bands and changes in intensity of bands in DGGE profiles. Salinity and $A_{\mathrm{w}}$ were the dominant factors significantly explaining these community differences (Figure 4b). DGGE profiles indicated much lower species richness of active Archaea (4-5 bands per profile) and minimal change over time (data not shown).

DGGE allowed us to identify samples for detailed analysis of the total bacterial community composition by construction of 454 pyrosequencing DNA amplicon libraries (16S rRNA gene), and so libraries were created from wet controls for days 1 and 28, from desiccated sediments for days 14 (salinity 144) and 23 (salinity 231) and from the reflooded sediments on day 28. UniFrac analysis of the libraries showed minimal changes in the bacterial community composition in the wet sediments from days 1 to 28 (Figure 5). The bacterial communities in the desiccated sediments were similar at days 14 and 23, but distinct from those in the wet sediments; and after tidal reflooding, a bacterial community developed that was distinct from those in both the wet and desiccated sediments. There was a non-significant decrease in 16S rRNA sequence diversity (Shannon diversity index based on RDP clustering at the $3 \%$ level; see Figure 5 for scores) in the desiccated sediments up to day 23 , followed by a significant decrease $(P<0.01)$ after reflooding.

Proteobacteria and Bacteriodetes dominated the wet control sediments (Table 1), and although they 
a

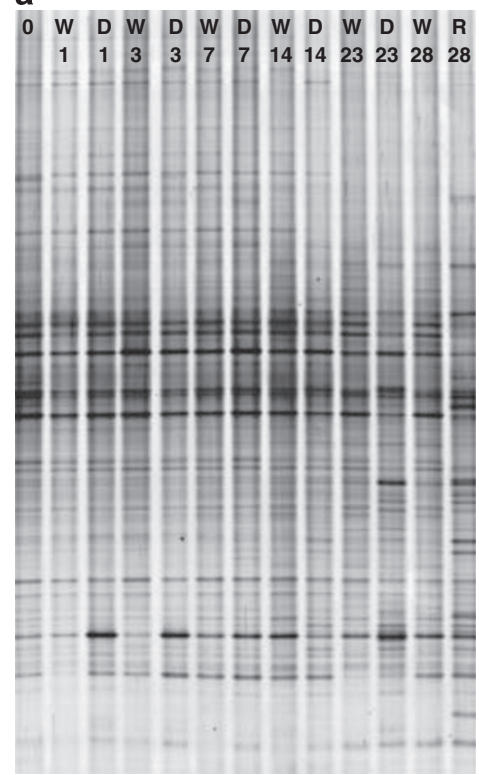

b

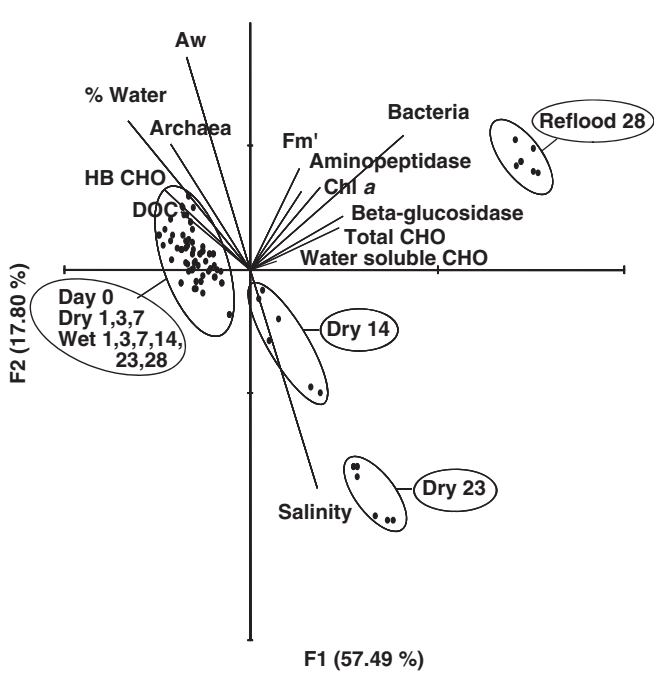

Figure 4 Shift in the active bacterial community composition on sediment desiccation and subsequent tidal reflooding as revealed by (a) DGGE profiles of PCR-amplified reverse-transcribed 16S rRNA from sediments (lanes labelled: W, wet; D, desiccating; R, reflooded; number: day) and (b) canonical correspondence analysis of replicate DGGE profiles linked to abiotic and biotic environmental variables (arrows as labelled). Circles represent DGGE profiles from sediment communities in wet, desiccating and reflooded sediments (as labelled), whereas lines indicate the direction of increasing values of the variable and the degree of correlation (line length) of that variable with the community data.

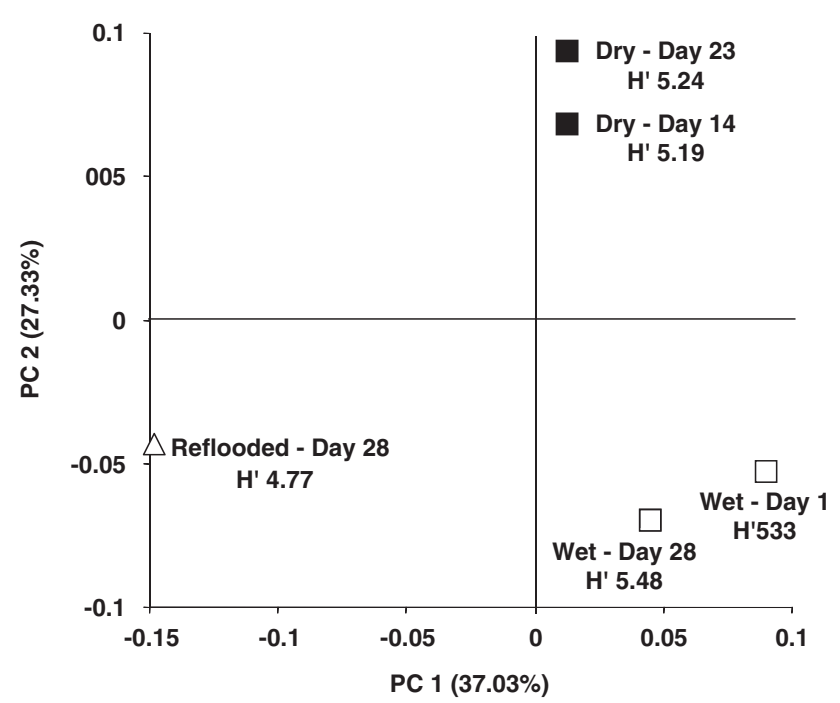

Figure 5 Change in community structure in desiccated and subsequently reflooded sediments relative to the wet control sediments (as labelled) as revealed by UniFrac principal component analysis of 16S rRNA gene 454 pyrosequencing libraries. Comparison is based on the UniFrac metric, which measures the difference between the libraries in terms of the branch length that is unique to one library or the other after a phylogeny construction of $\sim 4250$ sequences. Shannon diversity scores $\left(\mathrm{H}^{\prime}\right)$ calculated from RDP alignment and clustering at the $3 \%$ level.

remained dominant on desiccation, there was a reduction in the relative abundance of the Bacteroidetes and increases in the Alphaproteobacteria and
Gammaproteobacteria. Numerous families or genera of Bacteria increased in relative abundance in the desiccating sediment, including a $70 \%$ increase in the Rhodobacteraceae (to $11 \%$ ) and a sixfold increase in the Thiotricales (to 5\%), which was particularly due to increases in Methylophaga. Sediment desiccation also resulted in the appearance of Halobacillus $(0.5 \%$ in dry 23 ; absent from wet libraries) and a sixfold increase in Marinobacter (to $1.9 \%$ ).

After reflooding of the desiccated sediments, the Gammaproteobacteria increased to $39 \%$, particularly as Marinobacter sequences increased further to $9.4 \%$ of the library (Table 1). A threefold increase in the Bacteroidetes was evident (up to $19.9 \%$ from $6.5 \%$ in the desiccated sediments), mainly because of increases of sequences assigned to Flavobacteriales and Sphingobacteriales that had earlier decreased during desiccation. A twofold decrease in Deltaproteobacteria (down to $8 \%$ ) was observed, mainly owing to a fewer sequences from Desulfobacterales.

Within the Flavobacteriales, we identified several clusters containing sequences from only dry and/or reflooded sediments. Of these, one cluster of sequences was $\sim 97 \%$ similar to those from Robiginitalea spp., earlier found in diverse marine environments including coastal sediments and a hypersaline microbial mat (Manh et al., 2008). Cluster analysis also revealed other groups confined to reflooded sediments, such as Alcanivoraceae from the Oceanospirillales, whereas a cluster 
Table 1 Relative abundance (\%) of 16S rRNA bacterial sequences in 454 pyrosequencing libraries from the wet control (W1 and W28), desiccated (D14 and D23) and reflooded (R28) sediments

W1 W28 D14 D23 R28

Relative abundance (\%)

Acidobacteria; acidobacteriaceae

Actinobacteria

Bacteroidetes

Bacteroidales

Flavobacteriales

Sphingobacteriales

Unclassified bacteroidetes

Chloroflexi

Deferribacteres; Deferribacterales

Firmicutes

Bacillaceae; Halobacillus

Paenibacillaceae; Paenibacillus

Clostridiaceae

Fusobacteria; Leptotrichia

Gemmatimonadetes;

Gemmatimonadaceae

Lentisphaerae; Lentisphaerae

Nitrospira; Nitrospiraceae

Alphaproteobacteria

Kordiimonas

Rhizobiales

Rhodobacteraceae

Rhodospirillales

Rickettsia

Sphingomonadaceae

Unclassified

Alphaproteobacteria

Betaproteobacteria

Deltaproteobacteria

Bacteriovorax

Desulfobacterales

Desulfovibrionaceae

Desulfuromonales

Myxococcales

Syntrophobacterales

Unclassified deltaproteobacteria

Epsilonproteobacteria;

Campylobacterales

Gammaproteobacteria

Marinobacter)

Marinobacter

Chromatiales

Enterobacteriaceae

Legionellales

Oceanospirillales

Pseudomonadaceae

Thiotrichales (not including

Methylophaga) Methylophaga

Unclassified gammaproteobacteria Vibrio

Xanthomonadaceae

Unclassified proteobacteria

Spirochaeta

TM7

Unclassified bacteria

Verrucomicrobia; Verrucomicrobiales

WS3

Cyanobacteria

Unclassified (below 90\%

similarity to any RDP sequence)

A total of $\sim 4250$ sequences (850 per library) were included in the analysis.

$\begin{array}{lllll}0.1 & 0.3 & 0.5 & 1.9 & 9.4\end{array}$

$\begin{array}{rrrrr}10.2 & 9.7 & 12.4 & 10.1 & 12.3\end{array}$

$\begin{array}{lllll}0.0 & 0.1 & 0.2 & 0.2 & 0.0\end{array}$

$\begin{array}{lllll}0.0 & 0.5 & 0.0 & 0.1 & 0.3\end{array}$

$\begin{array}{lllll}0.5 & 1.0 & 0.8 & 0.7 & 3.3\end{array}$

$\begin{array}{lllll}0.3 & 0.6 & 0.2 & 0.3 & 0.1\end{array}$

$\begin{array}{lllll}0.6 & 0.3 & 0.7 & 1.7 & 0.5\end{array}$

$\begin{array}{lllll}0.0 & 0.5 & 1.6 & 3.3 & 0.7\end{array}$

$\begin{array}{rrrrr}17.3 & 17.0 & 17.7 & 15.1 & 10.7\end{array}$

$\begin{array}{lllll}0.1 & 0.0 & 0.0 & 0.0 & 0.0\end{array}$

$\begin{array}{lllll}0.4 & 0.1 & 0.0 & 0.2 & 0.1\end{array}$

$\begin{array}{lllll}0.9 & 1.0 & 1.1 & 1.7 & 3.0\end{array}$

$\begin{array}{lllll}0.2 & 0.1 & 0.2 & 0.2 & 0.0\end{array}$

$\begin{array}{lllll}0.0 & 0.2 & 0.0 & 0.0 & 0.0\end{array}$

$\begin{array}{lllll}4.8 & 3.4 & 4.7 & 3.6 & 2.4\end{array}$

$\begin{array}{lllll}0.0 & 0.2 & 0.6 & 0.1 & 0.1\end{array}$

$\begin{array}{lllll}0.2 & 0.4 & 0.0 & 0.3 & 0.0\end{array}$

$\begin{array}{llllll}0.3 & 1.9 & 0.3 & 0.8 & 0.7\end{array}$

$\begin{array}{lllll}12.5 & 8.8 & 10.5 & 8.1 & 7.0\end{array}$ containing the versatile genus Nocardioides (Actinobacteria) was confined to dry sediments.

\section{Discussion}

Intertidal sediments are frequently subjected to desiccation, and so we investigated the effects of desiccation stress on the resistance and resilience, composition and functioning of the microbial community from the upper creek system of Colne Point saltmarsh. We have simulated a desiccation event typical of this and many other marshes worldwide. For example, sediment pore-water salinity can exceed 200 in the nearby Blackwater Estuary marshes (Underwood, 1997) and Arabian Gulf intertidal sediments (Abed et al., 2007), whereas coastal saltmarsh pans can experience salinities above 400 (Porter et al., 2007).

Water content decreased to $28 \%$, with pore-water salinity rising from 35 to 231 . At such high solute concentrations, the amount of water thermodynamically available to microbes becomes very limited. The mole fraction of water (water activity, $A_{\mathrm{w}}$ ) provides an indication of water that is available to cells (Brown, 1990). Growth at an $A_{\mathrm{w}}$ of 0.75 (saturated $\mathrm{NaCl}$ ) is limited largely to extremely halophilic Archaea (Brown, 1990; Hallsworth et al., 2007), and a few species of xerophilic fungi can grow slowly at an $A_{\mathrm{w}}$ of 0.65 (Williams and Hallsworth, 2009). Lowering the $A_{\mathrm{w}}$ of these coastal sediments to 0.84 (pore-water salinity of 240; equivalent to the $A_{\mathrm{w}}$ of salami) provides an extremely stressful environment for most microorganisms (Brown, 1990). Although many marine microbes can grow beyond seawater salinity, relatively few are known to grow at a salinity of 240 (Brown, 1990). In comparison, the control sediments maintained a relatively constant pore-water salinity and $A_{\mathrm{w}}$, with minimal changes in the behaviour and composition of the microbial community over the 28 days.

\section{Desiccation stress causes microbial behavioural changes and relocation of resources}

In the controls, MPB continued to exhibit diel vertical migration behaviour typical of that found in the intertidal environment (Consalvey et al., 2004; Underwood et al., 2005). In contrast, changes in diatom behaviour were evident even in the earlier stages of sediment desiccation (from day 7 , salinity 83) as many disappeared from the sediment surface (Figure 2d) presumably adopting an avoidance strategy by migrating to wetter sediment below. At the most extreme point of desiccation, almost no diatoms could be imaged on the surface. The imaging detects all surface microalgae that contain Chl $a$ to a depth of approximately the top $200 \mu \mathrm{m}$ (Kromkamp et al., 1998, Perkins et al., 2002). This reflects cells in the photic zone of the sediment. 
Cells vertically migrating deeper than this will not be measured, but may remain viable at depth. This seems to have happened with viable MPB seeking refuge in deeper layers and returning to the surface on rewetting. Diatoms are known to migrate deeper in response to temperature and light stress (Underwood, 2002), whereas salinities above 35 have led to fewer cells migrating vertically (Sauer et al., 2002) with cessation of motility observed at high salinity (140) (Apoya-Horton et al., 2006). We conclude that as the sediment surface dried to a critical point, the benthic diatoms ceased their upwards migration and remained at depth in the sediment.

Although MPB had moved from the surface, Chl $a$ increased in the top $2 \mathrm{~mm}$ of the sediment, possibly because of elevated Chl $a$ production, which would improve light harvesting and so compensate for the lower light levels below the surface. Increased Chl $a$ is a common response to decreased light levels among algae (Smith and Melis, 1988; Teramoto et al., 2002). Increased standing stocks of Chl a could also be a result of reduced Chl $a$ degradation as heterotrophic microbial activity slowed down. The rapid recovery of the MPB assemblage on reflooding suggests that a large proportion of these diatoms remained viable in the dry sediment.

Water mediates the diffusion of substrates into cells and is required for enzymatic hydrolysis of biopolymers, and in an environment of decreasing $A_{\mathrm{w}}$, water available for such reactions becomes limiting. Effects of reducing $A_{\mathrm{w}}$ on the activity of the bacterial community were apparent from the decrease in both $\beta$-glucosidase and aminopeptidase activity over the first 14 days. The $\beta$-glucosidase hydrolysis rates in intertidal sediments have been shown to be optimal at a salinity of 30 , with rates decreasing twofold when salinity increased to 45 (King, 1986). Often, extracellular enzyme activity correlates with concentration of available organic substrate (Boschker and Cappenberg, 1998; Nausch and Kerstan, 2003) and can increase exponentially on sudden increases in substrate concentration (Arrieta and Herndl, 2002). Here, extracellular enzyme activity decreased during sediment desiccation despite a greater availability of labile carbohydrate and DOC (Figure 3). The reduction in enzyme activity may be attributed partly to the fact that stressed microorganisms need to relocate resources from growth pathways to producing protective molecules (Schimel et al., 2007) such as compatible solutes, chaperones or EPS (Roberson and Firestone, 1992; Tamaru et al., 2005; Sakamoto et al., 2009). EPS can retain water, creating hydrated bacterial microenvironments within the desiccating sediment (Roberson and Firestone, 1992), and this property of EPS is often cited as an important attribute in biofilm ecology (Decho, 1990). The difficulty remains in measuring the environment at a scale relevant to a single cell. The $A_{\mathrm{w}}$ reported (Figure 1) represents bulk measures from the top $2 \mathrm{~mm}$ of the sediment, yet because of EPS production and the heterogeneity of sediment structure, microenvironments of higher $A_{\mathrm{w}}$ probably provide refuge for some microorganisms.

\section{Desiccation alters intertidal carbon cycling and the DOC pool}

Initial increases in water-soluble carbohydrate and DOC, and the decrease in bacterial and archaeal numbers, suggest that desiccation events may be responsible for the recycling of considerable amounts of microbial carbon back to the DOC pool. Numerous factors may contribute to these early increases in carbohydrate and DOC in the desiccating sediment. First, lower-molecular-weight fixed carbon secreted by the MPB would be used quickly by bacteria (Cook et al., 2007; Hofmann et al., 2009); however, reductions in enzyme activity would cause a net increase in sediment concentrations if 'new' carbohydrate production remained constant. Second, bacteria and diatoms are likely to synthesize organic compatible solutes to protect from desiccation and increased salinity (van Bergeijk et al., 2003; Garza-Sanchez et al., 2009); such compounds can be secreted or leak from cells, and may be liberated by cell lysis of those microbes that are unable to tolerate the increasing osmotic stress. Third, total bacterial mortality in intertidal sediments, potentially from many sources (for example grazing, viral lysis, thermal and salinity stress), has been shown to be the primary fate (up to 65\%) of bacterial production (van Oevelen et al., 2006), with the released carbon being recycled back to the DOC pool. Death of many bacteria was likely given the large reductions in numbers during desiccation (Figure 2c), but whether or not the diatoms contributed to such a release of DOC through cellular lysis remains unclear. There were no dead diatoms at the surface, but we were unable to determine whether any had died at depth. Survival of many is likely given the large numbers that returned to the surface after the reflood, and given that many species will be adapted to desiccation and numerous diatoms have earlier been shown to tolerate and even grow at hypersaline conditions (Admiraal, 1977; Clavero et al., 2000).

Alternatively or additionally, much of the increase in water-soluble carbohydrate and DOC may be attributed to the fact that carbon is not transported to the water column during desiccation periods. Loss of water-soluble carbohydrate during tidal immersion can be considerable; $80-90 \%$ of colloidal and EPS carbohydrate production in the emersion period can be lost during the following tidal cover, with approximately half lost to bacterial degradation and the other half washed away with the tide (Hanlon et al., 2006).

From days 7 to 23 , enzyme activity remained low, but constant in the desiccating sediment and carbohydrate and DOC concentrations began to decline, suggesting that a proportion of the bacterial 
community remained metabolically active and that production of new DOC declined. Concentrations were similar in both the desiccated and wet sediments by day 23 (Figures 3c and d). Only the concentrations of carbohydrate and DOC were measured at each time point; therefore, it is difficult to comment on how production and turnover was affected, although given the reductions in enzyme activity and bacterial biomass, it is likely that carbon turnover was significantly depressed in the desiccated sediments. The disappearance of diatoms from the sediment surface, cessation of diurnal vertical migration and thus a reduction in their capacity to use available light optimally are likely to result in changes in both the production and turnover of fixed carbon. For example, the majority of diatom EPS is typically produced during tidal emersion, strongly linked to migration, and associated with diatoms in the uppermost surface layer (Smith and Underwood, 1998; Underwood and Paterson, 2003).

Bacterial communities are restructured on sediment desiccation and tidal reflooding

There were clear changes in both the active (RNA DGGE analysis; Figure 4) and total (DNA 454 pyrosequencing; Figure 5; Table 1) bacterial community composition in the desiccating sediments. Selection for known halophiles in the desiccated sediments included Halobacillus, a genus that includes Halobacillus halophilus, which was isolated from a North Sea saltmarsh (Claus et al., 1983) and possesses strategies to live in hypersaline environments (Saum and Muller, 2008). Halobacillus increased to $0.5 \%$ of the total sequences on extreme desiccation (day 23; salinity 231), and must exist in the sediments in low abundance before desiccation, because Halobacillus sequences remained undetected in the wet controls and even at day 14 of desiccation (Table 1), thus providing a good example of the redundancy of the sediment community that contributes to its resilience.

Sequences from Marinobacter and Roseovarius species, both known to tolerate high salinities (Labrenz et al., 1999; Biebl et al., 2005; Duran, 2010) also became more abundant in the desiccated sediments (Table 1). The cyanobacteria Microcoleus and Lyngbya have a high capacity to withstand desiccation in intertidal mats (Potts, 1999). Sequences assigned to these genera were found in libraries from both the wet control and desiccating sediments, suggesting that this was the case, although there was no increase in their relative abundance. Approximately $7-10 \%$ of sequences in each library remained unassigned. Clusters of the unclassified sequences (below 90\% similarity to any sequence in the RDP; Table 1) contained sequences derived from wet control and dry sediments, except for one cluster of 24 sequences confined to dry and reflooded sediments, which can only be assigned with confidence to the level of class, Proteobacteria.
The new information about the halophilic phenotype and phylogeny of this novel group could guide its cultivation.

Many members of the bacterial community are adapted to life in the upper intertidal zone, as shown by minimal detectable changes in community composition before day 14 (salinity 150). However, it is also apparent that some Bacteria are unable to cope with such extreme desiccation events given the reduction in diversity and large decrease in 16S rRNA gene abundance. For example, the decrease in Bacteroidetes in the desiccated sediments (Table 1) suggests the death of many from this group. In the drying sediments of temporary Mediterranean rivers, sharp declines of up to $100 \%$ and $74 \%$ of bacterial production and biomass, respectively, have been observed, as well as relative increases in Alphaproteobacteria and Betaproteobacteria (Amalfitano et al., 2008). Survivors may possess adaptation mechanisms to cope with high salinity, or may simply survive by chance in a microenvironment with higher $A_{\mathrm{w}}$. Another alternative may be to avoid the surface sediment by migration into deeper sediments. Numerous types of bacteria exhibit high migration rates in sediments either to exploit resources or to avoid stress (Whale and Walsby, 1984; Huettel et al., 1996). Some bacteria may also co-migrate while attached to diatom frustules or embedded in their EPS (Kaczmarska et al., 2005).

It is important to consider factors other than salinity stress and desiccation that may be affecting the changes in community composition. For example, gas exchange from the sediment to atmosphere will alter during the drying process, increasing diffusion rates and oxygen concentrations in the upper layers. Without measurements of such processes, it is difficult to draw definitive conclusions, but such factors may partly explain reductions in abundance of the anaerobic Desulfobacterales and increases in the aerobic Methylophaga. Availability of organic substrates will also affect community composition. The increases in Methylophaga sequences (Table 1) may, therefore, also be linked to the fact that numerous members of this genus are halotolerant and use a variety of C1 compounds (Vila-Costa et al., 2006; Neufeld et al., 2007), several of which derive from or serve as algal compatible solutes (for example dimethylsulphide and trimethylamine) that are likely to be produced in greater abundance in response to desiccation.

Although desiccation alters bacterial community composition, greater changes were evident after rewetting. The proportion of sequences from Marinobacter spp. increased moderately during desiccation. However, after rewetting, they became much more dominant ( $9.4 \%$ of sequences), presumably because of the founder effect coupled with their capacity to tolerate the sudden hypo-osmotic stress introduced by the incoming tide. In contrast, relative abundance of Rhizobiales decreased after 
the reflood (Table 1), which may be attributed to cellular lysis, as the intolerance of dried cells to sudden rewetting has earlier been reported (Kosanke et al., 1992). This sudden influx of water would lyse many other cells, releasing a source of readily degradable carbon. Dry periods in soils reduce biomass by up to a third, but it returns to earlier levels after rewetting, with the recovering populations using necromass as part of their growth requirements (Bottner, 1985). Such recovery was evident in our study, with $\beta$-glucosidase activity quickly returning to original values (Figure 3a) and bacterial numbers increasing to levels higher than before desiccation (Figure 2c). Similar patterns are observed in freshwater marshes in which drawdown and reflooding result in significant nutrient flux from the soils and stimulation of extracellular enzyme activities (Corstanje and Reddy, 2004). Rapid rewetting of dry soil resulted in community structure changes and short-term increases (1-4 days) in carbon mineralization rates, which may be linked to cell lysis or release of intracellular compatible solutes (Kieft et al., 1987; Fierer et al., 2003). Bacteria that cope with, or quickly recover from, the sudden hypo-osmotic stress of the reflood are in a favourable position because of the increase in organic growth substrates and nutrients. Thus, the increase in bacteria such as Flavobacteriales and Sphingobacteriales may be linked to their ability to use both high- and low-molecular-weight DOM (Kirchman, 2002), including EPS (Elifantz et al., 2005), their fast growth rates (Jurgens et al., 1999; Kirchman, 2002) and also their frequent close association with diatoms (Schafer et al., 2002; Grossart et al., 2005), which also returned in abundance to the sediment surface after the rewetting event.

\section{Conclusion}

Desiccation events in upper intertidal zones cause significant stress to microbial communities affecting microbial behaviour and processes as well as restructuring sediment communities. Our data suggest that biofilm functioning is changed in the first 5-10 days of drying (a regular occurrence in saltmarshes), with cells avoiding the surface, a reduction in photosynthesis and metabolic activity, but no major shifts in the microbial community composition. Longer periods of desiccation ( $>15$ days, a rarer event on UK marshes) had significant impacts on the microbial assemblages, particularly on bacterial numbers and composition, and all measures of microbial activity. Reflooding resulted in a rapid recovery by the benthic diatoms and biofilm activity (a high level of resilience with respect to functioning), but the formation of a different bacterial community after prolonged drying. Although the microbial community generally seemed to have the ability to adapt to, tolerate and recover quickly from desiccation and rewetting events, such community level effects may conceal significant changes in the bacterial composition of the biofilms.

\section{Conflict of interest}

The authors declare no conflict of interest.

\section{Acknowledgements}

We thank Tania Cresswell-Maynard and John Green for invaluable technical support. This work was funded by a grant to GJCU and TJM from the UK Natural Environment Research Council (NE/D003598/1).

\section{References}

Abed RMM, Kohls K, De Beer D. (2007). Effect of salinity changes on the bacterial diversity, photosynthesis and oxygen consumption of cyanobacterial mats from an intertidal flat of the Arabian Gulf. Environ Microbiol 9: 1384-1392.

Admiraal W. (1977). Salinity tolerance of benthic estuarine diatoms as tested with a rapid polarographic measurement of photosynthesis. Mar Biol 39: 11-18.

Amalfitano S, Fazi S, Zoppini A, Caracciolo AB, Grenni P, Puddu A. (2008). Responses of benthic bacteria to experimental drying in sediments from Mediterranean temporary rivers. Microb Ecol 55: 270-279.

Apoya-Horton MD, Yin L, Underwood GJC, Gretz MR. (2006). Movement modalities and responses to environmental changes of the mudflat diatom Cylindrotheca closterium (Bacillariophyceae). J Phycol 42: 379-390.

Arrieta JM, Herndl GI. (2002). Changes in bacterial betaglucosidase diversity during a coastal phytoplankton bloom. Limnol Oceanogr 47: 594-599.

Bellinger BJ, Abdullahi AS, Gretz MR, Underwood GJC. (2005). Biofilm polymers: relationship between carbohydrate biopolymers from estuarine mudflats and unialgal cultures of benthic diatoms. Aquat Microb Ecol 38: 169-180.

Berges JA, Franklin DJ, Harrison PJ. (2001). Evolution of an artificial seawater medium: improvements in enriched seawater, artificial water over the last two decades. J Phycol 37: 1138-1145.

Biebl H, Allgaier M, Lunsdorf H, Pukall R, Tindall BJ, Wagner-Dobler I. (2005). Roseovarius mucosus sp nov., a member of the Roseobacter clade with trace amounts of bacteriochlorophyll a. Int J Syst Evol Microbiol 55: 2377-2383.

Boschker HTS, Cappenberg TE. (1998). Patterns of extracellular enzyme activities in littoral sediments of Lake Gooimeer, The Netherlands. FEMS Microbiol Ecol 25: 79-86.

Bottner P. (1985). Response of microbial biomass to alternate moist and dry conditions in a soil incubated with ${ }^{14} \mathrm{C}$-labeled and ${ }^{15} \mathrm{~N}$-labelled plant material. Soil Biol Biochem 17: 329-337.

Brown AD. (1990). Microbial Water Stress Physiology. Principles and Perspectives. John Wiley \& Sons, Chichester, UK. 
Chen GQ, Jiang Y, Chen F. (2008). Salt-induced alterations in lipid composition of diatom Nitzschia laevis (Bacillariophyceae) under heterotrophic culture condition. J Phycol 44: 1309-1314.

Claus D, Fahmy F, Rolf HJ, Tosunoglu N. (1983). Sporosarcina halophila sp. nov, an obligate, slightly halophilic bacterium from saltmarsh soils. Syst Appl Microbiol 4: 496-506.

Clavero E, Hernandez-Marine M, Grimalt JO, GarciaPichel F. (2000). Salinity tolerance of diatoms from thalassic hypersaline environments. J Phycol 36: 1021-1034.

Consalvey M, Paterson DM, Underwood GJC. (2004). The ups and downs of life in a benthic biofilm: migration of benthic diatoms. Diatom Res 19: 181-202.

Cook PLM, Veuger B, Boer S, Middelburg JJ. (2007). Effect of nutrient availability on carbon and nitrogen incorporation and flows through benthic algae and bacteria in near-shore sandy sediment. Aquat Microb Ecol 49: 165-180.

Corstanje R, Reddy KR. (2004). Response of biogeochemical indicators to a drawdown and subsequent reflood. J Environ Qual 33: 2357-2366.

Csonka LN. (1989). Physiological and genetic responses of bacteria to osmotic-stress. Microbiol Rev 53: 121-147.

Decho AW. (1990). Microbial exopolymer secretions in ocean environments: their role(s) in food webs and marine processes. Oceanogr Mar Biol Ann Rev 28: 73-153.

Dubois M, Gilles KA, Hamilton JK, Rebers PA, Smith F. (1956). Colorimetric method for determination of sugars and related substances. Anal Chem 28: $350-356$.

Duran R. (2010). Marinobacter. In: Timmis KN (ed). Handbook of Hydrocarbon and Lipid Microbiology. Springer: Berlin, Germany, Vol 3, pp 1726-1734.

Elifantz H, Malmstrom RR, Cottrell MT, Kirchman DL. (2005). Assimilation of polysaccharides and glucose by major bacterial groups in the Delaware Estuary. Appl Environ Microbiol 71: 7799-7805.

Fierer N, Schimel JP, Holden PA. (2003). Influence of drying-rewetting frequency on soil bacterial community structure. Microb Ecol 45: 63-71.

Garza-Sanchez F, Chapman DJ, Cooper JB. (2009). Nitzschia ovalis (Bacillariophyceae) Mono Lake strain accumulates 1,4/2,5 cyclohexanetetrol in response to increased salinity. J Phycol 45: 395-403.

Grossart HP, Levold F, Allgaier M, Simon M, Brinkhoff T. (2005). Marine diatom species harbour distinct bacterial communities. Environ Microbiol 7: 860-873.

Guarini JM, Blanchard GF, Gros P, Gouleau D, Bacher C. (2000). Dynamic model of the short-term variability of microphytobenthic biomass on temperate intertidal mudflats. Mar Eco Prog Ser 195: 291-303.

Hallsworth JE, Yakimov MM, Golyshin PN, Gillion JLM, D'Auria G, de Lima Alves F et al. (2007). Limits of life in $\mathrm{MgCl}_{2}$-containing environments: chaotropicity defines the window. Environ Microbiol 9: 801-813.

Hanlon ARM, Bellinger B, Haynes K, Xiao G, Hofmann TA, Gretz MR et al. (2006). Dynamics of extracellular polymeric substance (EPS) production and loss in an estuarine, diatom-dominated, microalgal biofilm over a tidal emersion-immersion period. Limnol Oceanogr 51: 79-93.

Haynes K, Hofmann TA, Smith CJ, Ball AS, Underwood GJC, Osborn AM. (2007). Diatom-derived carbohydrates as factors affecting bacterial community composition in estuarine sediments. Appl Environ Microbiol 73: 6112-6124.

Hofmann T, Hanlon ARM, Taylor JD, Ball AS, Osborn AM, Underwood GJC. (2009). Dynamics and compositional changes in extracellular carbohydrates in estuarine sediments during degradation. Mar Ecol Prog Ser 379: 45-58.

Hoppe HG. (1983). Significance of exoenzymatic activities in the ecology of brackish water: measurements by means of methylumbelliferyl substrates. Mar Ecol Prog Ser 11: 299-308.

Huettel M, Forster S, Kloser S, Fossing H. (1996). Vertical migration in the sediment-dwelling sulfur bacteria Thioploca spp. in overcoming diffusion limitations. Appl Environ Microbiol 62: 1863-1872.

IPCC (2007). Summary for policymakers. In: Solomon S, Qin D, Manning M, Chen Z, Marquis M, Averyt KB, Tignor M, and Miller HL (eds). Climate Change 2007: The Physical Science Basis. Contribution of Working Group I to the Fourth Assessment Report of the Intergovernmental Panel on Climate Change. Cambridge University Press: Cambridge, UK.

Jurgens K, Pernthaler J, Schalla S, Amann R. (1999). Morphological and compositional changes in a planktonic bacterial community in response to enhanced protozoan grazing. Appl Environ Microbiol 65: 1241-1250.

Kaczmarska I, Ehrman JM, Bates SS, Green DH, Leger C, Harris J. (2005). Diversity and distribution of epibiotic bacteria on Pseudo-nitzschia multiseries (Bacillariophyceae) in culture, and comparison with those on diatoms in native seawater. Harmful Algae 4: 725-741.

Kieft TL, Soroker E, Firestone MK. (1987). Microbial biomass response to a rapid increase in water potential when dry soil is wetted. Soil Biol Biochem 19: 119-126.

King GM. (1986). Characterization of beta-glucosidase activity in intertidal marine sediments. Appl Environ Microbiol 51: 373-380.

Kirchman DL. (2002). The ecology of Cytophaga-Flavobacteria in aquatic environments. FEMS Microbiol Ecol 39: 91-100.

Kirst GO. (1990). Salinity tolerance of eukaryotic marine algae. Annu Rev Plant Physiol Plant Mol Biol 41: 21-53.

Kosanke JW, Osburn RM, Shuppe GI, Smith RS. (1992). Slow rehydration improves the recovery of dried bacterial populations. Can J Microbiol 38: 520-525.

Kromkamp J, Barranguet C, Peene J. (1998). Determination of microphytobenthos PSII quantum efficiency and photosynthetic activity by means of variable chlorophyll fluorescence. Mar Ecol Prog Ser 162: 45-55.

Labrenz M, Collins MD, Lawson PA, Tindall BJ, Schumann P, Hirsch P. (1999). Roseovarius tolerans gen.nov., sp.nov., a budding bacterium with variable bacteriochlorophyll a production from hypersaline Ekho Lake. Int J Syst Bacteriol 49: 137-147.

Lee ZM, Bussema C, Schmidt TM. (2009). rrnDB: documenting the number of rRNA and tRNA genes in bacteria and archaea. Nucleic Acids Res 37: D489-D493.

Lorenzen CJ. (1967). Determination of chlorophyll and phaeopigments: spectrophotometric equations. Limnol Oceanogr 12: 343-346.

Manh HD, Matsuo Y, Katsuta A, Matsuda S, Shizuri Y, Kasai H. (2008). Robiginitalea myxolifaciens sp.nov. a novel myxol-producing bacterium isolated from 
marine sediment, and emended description of the genus Robiginitalea. Int $J$ Syst Evol Microbiol 58: 1660-1664.

Nausch M, Kerstan E. (2003). The relationship between dissolved carbohydrates and carbohydrate-degrading enzymes in the salinity gradient of the Pomeranian Bight (southern Baltic). Oceanologia 45: 437-452.

Neufeld JD, Schafer H, Cox MJ, Boden R, McDonald IR, Murrell JC. (2007). Stable-isotope probing implicates Methylophaga spp and novel Gammaproteobacteria in marine methanol and methylamine metabolism. ISME J 1: 480-491.

Oxborough K, Hanlon ARM, Underwood GJC, Baker NR. (2000). In vivo estimation of the photosystem II photochemical efficiency of individual microphytobenthic cells using high-resolution imaging of chlorophyll a fluorescence. Limnol Oceanogr 45: 1420-1425.

Perkins RG, Oxborough K, Hanlon ARM, Underwood GJC, Baker NR. (2002). Can chlorophyll fluorescence be used to estimate the rate of photosynthetic electron transport within microphytobenthic biofilms? Mar Ecol Prog Ser 228: 47-56.

Porter D, Roychoudhury AN, Cowan D. (2007). Dissimilatory sulfate reduction in hypersaline coastal pans: activity across a salinity gradient. Geochim Cosmochim Acta 71: 5102-5116.

Potts M. (1999). Mechanisms of desiccation tolerance in cyanobacteria. Eur J Phycol 34: 319-328.

Roberson EB, Firestone MK. (1992). Relationship between desiccation and exopolysaccharide production in a soil Pseudomonas sp. Appl Environ Microbiol 58: 1284-1291.

Rothrock MJ, Garcia-Pichel F. (2005). Microbial diversity of benthic mats along a tidal desiccation gradient. Environ Microbiol 7: 593-601.

Round FE, Crawford RM, Mann DG. (1990). The Diatoms, Biology and Morphology of the Genera. Cambridge University Press: Cambridge.

Sakamoto T, Yoshida T, Arima H, Hatanaka Y, Takani Y, Tamaru Y. (2009). Accumulation of trehalose in response to desiccation and salt stress in the terrestrial cyanobacterium Nostoc commune. Phycological Res 57: $66-73$.

Sauer J, Wenderoth K, Maier UG, Rhiel E. (2002). Effects of salinity, light and time on the vertical migration of diatom assemblages. Diatom Res 17: 189-203.

Saum SH, Muller V. (2008). Regulation of osmoadaptation in the moderate halophile Halobacillus halophilus: chloride, glutamate and switching osmolyte strategies. Saline Syst 4: 4.

Schafer H, Abbas B, Witte H, Muyzer G. (2002). Genetic diversity of 'satellite' bacteria present in cultures of marine diatoms. FEMS Microbiol Ecol 42: 25-35.

Schimel J, Balser TC, Wallenstein M. (2007). Microbial stress-response physiology and its implications for ecosystem function. Ecology 88: 1386-1394.

Simon M, Grossart H-P, Schweitzer B, Ploug H. (2002). Microbial ecology of organic aggregates in aquatic ecosystems. Aquat Microb Ecol 28: 175-211.

Smith BM, Melis A. (1988). Photochemical apparatus organization in the diatom Cylindrotheca fusiformis: photosystem stoichiometry and excitation distribution in cells grown under high and low irradiance. Plant Cell Physiol 29: 761-769.

Smith DJ, Underwood GJC. (1998). Exopolymer production by intertidal epipelic diatoms. Limnol Oceanogr 43: 1578-1591.

Stal LJ, Vangemerden H, Krumbein WE. (1984). The simultaneous assay of chlorophyll and bacteriochlorophyll in natural microbial communities. J Microbiol Methods 2: 295-306.

Tamaru Y, Takani Y, Yoshida T, Sakamoto T. (2005). Crucial role of extracellular polysaccharides in desiccation and freezing tolerance in the terrestrial cyanobacterium Nostoc commune. Appl Environ Microbiol 71: 7327-7333.

Teramoto H, Nakamori A, Minagawa J, Ono T. (2002). Light-intensity-dependent expression of Lhc gene family encoding light-harvesting chlorophyll-a/b proteins of photosystem II in Chlamydomonas reinhardtii. Plant Physiol 130: 325-333.

Underwood GJC. (1994). Seasonal and spatial variation in epipelic diatom assemblages in the Severn estuary. Diatom Res 9: 451-472.

Underwood GJC. (1997). Microalgal colonization in a saltmarsh restoration scheme. Estuar Coast Shelf Sci 44: 471-481.

Underwood GJC. (2002). Adaptations of tropical marine microphytobenthic assemblages along a gradient of light and nutrient availability in Suva Lagoon, Fiji. Eur J Phycol 37: 449-462.

Underwood GJC, Kromkamp J. (1999). Primary production by phytoplankton and microphytobenthos in estuaries. Adv Ecol Res 29: 93-153.

Underwood GJC, Paterson DM. (2003). The importance of extracellular carbohydrate production by marine epipelic diatoms. Adv Bot Res 4: 183-240.

Underwood GJC, Perkins RG, Consalvey MC, Hanlon ARM, Oxborough K, Baker NR et al. (2005). Patterns in microphytobenthic primary productivity: species-specific variation in migratory rhythms and photosynthetic efficiency in mixed-species biofilms. Limnol Oceanogr 50: 755-767.

Underwood GJC, Phillips J, Saunders K. (1998). Distribution of estuarine benthic diatom species along salinity and nutrient gradients. Eur J Phycol 33: 173-183.

van Bergeijk SA, Van der Zee C, Stal LJ. (2003). Uptake and excretion of dimethylsulphoniopropionate is driven by salinity changes in the marine benthic diatom Cylindrotheca closterium. Eur J Phycol 38: 341-349.

van Oevelen D, Middelburg JJ, Soetaert K, Moodley L. (2006). The fate of bacterial carbon in an intertidal sediment: modeling an in situ isotope tracer experiment. Limnol Oceanogr 51: 1302-1314.

Vila-Costa M, del Valle DA, Gonzalez JM, Slezak D, Kiene RP, Sanchez O et al. (2006). Phylogenetic identification and metabolism of marine dimethylsulfide-consuming bacteria. Environ Microbiol 8: 2189-2200.

Whale GF, Walsby AE. (1984). Motility of the cyanobacterium Microcoleus chthonoplastes in mud. Brit Phycol J 19: 117-123.

Williams JP, Hallsworth JE. (2009). Limits of life in hostile environments: no barriers to biosphere function? Environ Microbiol 11: 3292-3308. 